\title{
Effect of Storage Material and Location on Physicochemical Properties and Nutritional Composition of Stored Bread Wheat in Ethiopia
}

\author{
Cherinet Kasahun Olana \\ Food Science and Nutrition Research Directorate, Ethiopian Institute of Agricultural Research, Kulumsa Agricultural Research Center, \\ Assela, Ethiopia
}

Email address:

cherukas05@gmail.com

To cite this article:

Cherinet Kasahun Olana. Effect of Storage Material and Location on Physicochemical Properties and Nutritional Composition of Stored Bread Wheat in Ethiopia. Journal of Food and Nutrition Sciences. Vol. 9, No. 4, 2021, pp. 106-112. doi: 10.11648/j.jfns.20210904.12

Received: June 24, 2021; Accepted: July 14, 2021; Published: July 24, 2021

\begin{abstract}
Postharvest management intervention of wheat grain needs to be examined from technological quality perspectives before its introduction to end-users. Local and improved methods of grain storage cause a lot of losses in terms of physical and Physico-chemical properties. These losses could be improved by providing appropriate storage materials at all agro-ecologies. This study aimed to evaluate the effects of different grain storage materials on the physical and physicochemical properties of stored wheat at different locations. The experiment included three treatments; (Purdue Improved Crop Storage (PICS), polypropylene bags, and Jute bags) at different agro-ecological locations; midland (Debrezeit), lowland (Werer), and highland (Kulumsa). Wheat, Lemu variety was stored in triplicate (25 Kilogram/container) for six months (December 2018 - June 2018) under normal environmental conditions in a randomized complete block design (RCBD), with three replication times Wheat stored in Jute bag at lowland for 6 months had lower final germination percentage, lower gluten index, and higher falling number value. In addition, wheat stored at lowland in jute bag had reduced hardness index value. Meanwhile, wheat stored in a Jute bag at midland for 6 months had a lower final germination percentage, lower hectoliter weight but, insignificant change in the hardness index value. Wheat stored at low land, midland, and highland in a jute bag for 4 and 6 months had shown increment in protein content. Wheat stored at midland in jute bag and PICS for 6 months had lower hectoliter weight and flour yield percentage. Besides, wheat stored at midland in a jute bag for 4 months of storage had higher wet and dry gluten content but, lower gluten index value. This condition may pose a negative influence on the baking performance of flour from wheat stored at lowland and with traditional jut bags. From this study, it can be concluded that PICS bags at all storage sites had Significant effective storage materials to preserve wheat grains. Further investigation, however, is very important to evaluate the influence of these treatments on the end-use qualities including baking quality.
\end{abstract}

Keywords: PICS Bags, Wheat, Gluten, Hardness Index, Nutritional Composition

\section{Introduction}

Wheat is the staple food for most of the world's population. However, a lot of grain is damaged and/or wasted during storage particularly in developing countries where a huge quantity of grain is stored at the household level. A recent survey conducted in 2016 on nearly 150 farm stores found that the mean weight loss due to storage insects was about $1.5 \%$ [1]. Therefore, proper storage materials and conditions for wheat grains can bring about considerable improvement in the national economy through control in losses in both the quantity as well as quality [11]. Deterioration of produce may begin in fields before harvesting, which further aggravates during improper storage. Different factors such as improved varieties, use of inorganic fertilizer and increased awareness through extension education have contributed to significantly improve wheat productivity per unit area [5]. Despite these advances, Ethiopia still imports wheat for local consumption. In this context, improved post-harvest management practices may enhance food security in many African countries [6]. The primary factors affecting grain storage are moisture, temperature, and humidity of the storage environment. other factors responsible for deterioration are poor 
containers/warehouses, feeding by rodents, insect pests, and microorganisms. Post-harvest loss can occur at any stage along the post-harvest value chain. Understanding the circumstances around harvest and post-harvest operations for a given crop will help reduce post-harvest losses and improve the income of farm households. Improvements in postharvest management practices will help to avoid both quantitative and qualitative losses and maintain the quality of the grain for various end uses [7].

Both primary and secondary factors bring chemical changes and weight loss as well as changes in quality [12]. At the household level, wheat is stored either in threshed or unthreshed forms in smaller containers e.g. baskets and jars, hand-knitted bags (made from jute, palm leaves, cotton threads, paddy straws), earthenware jars, and/or polyethylene or propylene bags. The use of metal drums has also been recommended for use at the farm level [12]. Strategies such as use of filter cake, Triplex, and metal silos were tested for postharvest preservation of maize in the country. Recent reports by [2]. Wheat seed stored in gunny, cloth and plastic bags were in good terms with temperature, moisture content and germination capacity in comparison with those in metal and earthen bins [10].

Proper storage conditions for wheat grains can bring about considerable improvement in the national economy through control in postharvest losses, which may range from 10 to 15 percent for food grains [11]. The safe moisture contents for grain storage vary according to the type of cereal, for wheat, it varies between 14 to 15 percent at $25^{\circ} \mathrm{C}$ and 75 percent humidity. There are many secondary factors, which also contribute to losses which include poor containers or stores, mechanical damage, feeding by rodents, growth of insects and microorganisms. Losses in stored grains incurred due to physical (temperature, humidity) or technical (storage conditions, methods, and duration) are difficult to control under poor management conditions [9]. The association between the physical changes and the changes in the chemical composition of food has made the biochemical and nutritional quality control of the stored products increasingly essential [13].

On the other hands, the knowledge base on effectiveness of hermetic bags for wheat storage is also limited [4]. As to the knowledge of us, there is very limited or even no research-based information concerning the influence of the storage materials on wheat grain quality under different agroecologies. Limited information exists on postharvest preservation strategies of stored wheat in Ethiopia [3]. Thus, this study was implemented to identify suitable storage materials under different agro-ecologies applicable at the household levels.

\section{Materials and Methods}

\subsection{Wheat Grains Sampling}

Wheat Grains Samples of freshly harvested grains of bread wheat variety (Lemu) were collected during the cropping year of 2017/18 from the Wheat breeding research Program, Kulumsa Agricultural Research Center (KARC), Asella,
Ethiopia.

\subsection{Experimental Design}

The experiment was conducted for six months (December 2018 to June 2018) in the laboratory at Werer, Debrezeit, and Kulumsa research centers laboratories, Ethiopia. The storage treatments were placed at the ambient condition in the laboratory room $\left(\mathrm{L} \times \mathrm{W} \times \mathrm{H} \approx 1200 \mathrm{~m}^{3}\right)$. The experiment included three storage materials; (1) polypropylene bag, (2) Purdue Improved Crop Storage (PICS) bag, and (3) jute bag. All storage treatments, with a $50 \mathrm{~kg}$ grain holding capacity, were loaded with $25 \mathrm{~kg}$ wheat grain. The relative humidity (RH) and temperature of the storage room were monitored as described in [3] using a data logger.

Wheat (Lemu variety) was stored in triplicate (25 Kilogram/container) At Werer, Debrezeit, and Kulumsa research centers laboratories, for six months June 2018 December 2018) under normal environmental conditions in three different containers namely PICS bag, jute bag, and polypropylene bag. Daily records of temperature and humidity were maintained and the average annual mean relative humidity and temperature at Kulumsa, Debre Zeit, and Werer were 39.92 and 20.16, 58.22 and 26.5, 61.46 and 27.42 respectively. The storage room was well ventilated, with the door opened in the daytime. Physicochemical Analysis of samples was drawn after every two months based on the literature and analyzed in triplicate for parameters such as moisture, protein, test weight, flour yield, falling number, and gluten content according to standard methods of [8]. And all samples were analyzed in triplicate.

\subsubsection{Grain Physicochemical Properties}

\section{Moisture Content}

The moisture content of the wheat samples was analyzed through the NIR technique by using FOSS Infratec 1241 according to the procedure is given in MCC (2000) method No. 44-16.

Protein Content

The protein content of the wheat samples was determined by using the NIR technique by running the grain samples through FOSS infratec 1241 according to the procedure described in [8]. methozzd No. 39-11.

\subsubsection{Wheat Grain Physical Qqualities}

\section{Hectoliter Weight}

Test weight was measured in special Seed buro Filling Hopper (model 151) according to [8]. Method No. 55-10. After cleaning and passing through specific sieves, the hopper was filled with the sample. Excess grains were scraped off with a strike. Reading was noted on the scale and the result was calculated as $\mathrm{Kg} / \mathrm{hl}$.

Single Kernel Characterization

A single kernel characterization system was used for, kernel weight, diameter, hardness/softness, and moisture based on the [8]. method 55-31. A sample of wheat kernels (12-16 grams) was prepared by removing broken kernels, weed seeds, and other foreign matter, and then the sample 
was poured into the access hopper of the single kernel characterization system (SKCS) instrument. The SKCS instrument analyzes 300 kernels individually and records the results on a computer graph [8].

\subsection{Germination Percentage}

Seed germination of Lemu wheat variety stored for 6 months in PICS, Propylene, and Jute bag at different temperatures was determined by the standard method of examination; Filter paper was used as a sprouting base in sterilized Petri dishes. Seed germination was determined after 7 days of 100 seed germination tests has been done [14]. Millin

Chopin CD1 miller was used to determine the milling behavior of tempered wheat grains and flour yield according to AACC Method No. 26-50. 500-grams sample of wheat grain was tempered to $16.5 \%$ moisture level for gentle removal of bran from endosperm. The mill was operated according to the manufacturer's instructions and run for 30 minutes for complete grinding and sieving into four fractions as thick bran, fine bran, fine flour, and coarse flour or shorts. Fine flour and thick flour were combined, weighed and flour yield was calculated.

\subsection{Gluten Quantity and Quality}

Gluten quantity and quality were determined according to the [8]. Method. A Ten-gram sample of flour or ground wheat was weighed and placed into the (glutomatic washing chamber, 2200 Sweden) on top of the polyester screen. The sample was then mixed and washed with a 2 percent salt solution $(2 \%$ of $\mathrm{NaCl})$ for 5 minutes. The wet gluten was then removed from the washing chamber, placed in the centrifuge holder, and centrifuged. The residue remained on top of the screen and through the screen was weighed. Then the total gluten was dried in glutork, and then the wet gluten, dry gluten, and gluten index were calculated.

\subsection{Falling Number}

Falling Number was determined by using the instrument "Falling No. 1500" according to [8] method No. 02-06. A
Suspension of flour was prepared by adding $25 \mathrm{ml}$. distilled water in 7 grams (at 14\% moisture level) wheat flour in falling Number tube. The tubes were inserted into the preheated apparatus and operated according to the instructions given in the user manual. The suspension was heated to gelatinize the starch of flour; time counted in seconds to drop down a plunger having definite weight into the gelatinized flour paste was recorded as Falling Number.

\subsection{Statistical Analysis}

Data obtained from the laboratory analysis were evaluated using two ways ANOVA and the significance of means was declared at $\mathrm{p} \leq 0.05$ and mean separation was carried out with Least Significant Difference (LSD) comparison. SPSS software version 20 was used for the statistical analysis.

\section{Results and Discussion}

As table 1 describes wheat stored in PICS, Propylene and Jute bag at Werer, Debrezeit, and Kulumsa for 2 months had no significant difference from the control in hardness, weight, and diameter except Kulumsa PICS (29.49 mg, $2.48 \mathrm{~mm}$ respectively) and Propylene (30.59 $\mathrm{mg}, 2.52 \mathrm{~mm}$ ), which have shown a significant decrease in weight and diameter to the control $(31.62 \mathrm{mg}, 2.58 \mathrm{~mm}$ respectively) of the wheat stored for 2 months.

As described in table 1 wheat stored in PICS, Polypropylene and Jute bag at Werer, Debrezeit, and Kulumsa for 4 months had no significant difference from the control in hardness, weight, and diameter except Kulumsa Propylene which have shown a significant decrease in hardness and weight $(75.81 \%$, $29.69 \mathrm{mg}$ respectively ) compared to the control $(79.78 \%$, $31.62 \mathrm{mg}$ respectively ); meanwhile Debrezeit Jute bag has shown a significant increase in hardness $(82.10 \%)$ compared to the control $(79.78 \%)$ of the wheat stored for 4 months. Whereas, Debrezeit Propylene has shown a significant decrease in weight and diameter $(28.81 \mathrm{mg}, 2.49 \mathrm{~mm})$ as compared to the control weight and diameter $(31.62 \mathrm{mg}, 2.58$ $\mathrm{mm}$ respectively).

Table 1. Grain hardness, weight and diameter of wheat stored at highland, midland and lowland in PICS, propylene, and jute bag after 2, 4 and 6 months respectively of storage.

\begin{tabular}{|c|c|c|c|c|c|}
\hline Storage material & Location & Duration & Hardness index (\%) & Kernel weight (mg) & Kernel diameter $(\mathrm{mm})$ \\
\hline \multirow{3}{*}{ PICS } & Werer & 2 months & $79.75 \pm 0.73^{\mathrm{a}}$ & $31.59 \pm 1.01^{\text {acd }}$ & $2.49 \pm 0.04^{\mathrm{acd}}$ \\
\hline & Debrezeit & 2 months & $78.53 \pm 1.05^{\mathrm{a}}$ & $31.42 \pm 0.87^{\mathrm{ac}}$ & $2.59 \pm 0.04^{\mathrm{ac}}$ \\
\hline & Kulumsa & 2 months & $80.09 \pm 0.12^{\mathrm{a}}$ & $29.49 \pm 0.56^{\mathrm{b}}$ & $2.48 \pm 0.03^{\mathrm{b}}$ \\
\hline \multirow{3}{*}{ Polypropylene } & Werer & 2 months & $79.70 \pm 1.26^{\mathrm{ac}}$ & $30.78 \pm 0.28^{\mathrm{ab}}$ & $2.58 \pm 0.01^{\mathrm{abc}}$ \\
\hline & Debrezeit & 2 months & $79.56 \pm 1.08^{\mathrm{ac}}$ & $31.15 \pm 0.09^{\mathrm{ac}}$ & $2.63 \pm 0.02^{b c}$ \\
\hline & Kulumsa & 2 months & $76.0 \pm 1.16^{\mathrm{ab}}$ & $30.59 \pm 0.62^{b}$ & $2.52 \pm 0.04^{\mathrm{b}}$ \\
\hline \multirow{3}{*}{ Jute bag } & Werer & 2 months & $81.0 \pm 1.03^{\mathrm{a}}$ & $31.61 \pm 0.52^{\mathrm{a}}$ & $2.61 \pm 0.03^{\mathrm{a}}$ \\
\hline & Debrezeit & 2 months & $80.64 \pm 1.13^{\mathrm{a}}$ & $32.97 \pm 1.51^{\mathrm{a}}$ & $2.63 \pm 0.07^{\mathrm{a}}$ \\
\hline & Kulumsa & 2 months & $81.07 \pm 0.60^{\mathrm{a}}$ & $31.52 \pm 1.04^{\mathrm{a}}$ & $2.57 \pm 0.05^{\mathrm{a}}$ \\
\hline \multirow{3}{*}{ PICS } & Werer & 4 months & $77.70 \pm 1.43^{\mathrm{a}}$ & $31.12 \pm 1.35^{\mathrm{a}}$ & $2.59 \pm 0.06^{\mathrm{a}}$ \\
\hline & Debrezeit & 4 months & $79.59 \pm 1.10^{\mathrm{a}}$ & $29.63 \pm 0.58^{b}$ & $2.53 \pm 0.03^{\mathrm{a}}$ \\
\hline & Kulumsa & 4 months & $78.07 \pm 0.73 a$ & $31.18 \pm 1.06^{\mathrm{a}}$ & $2.60 \pm 0.07^{\mathrm{a}}$ \\
\hline \multirow{3}{*}{ Polypropylene } & Werer & 4 months & $79.11 \pm 1.31^{\mathrm{ac}}$ & $31.51 \pm 1.22^{\mathrm{a}}$ & $2.61 \pm 0.05^{\mathrm{ad}}$ \\
\hline & Debrezeit & 4 months & $78.42 \pm 0.65^{\mathrm{ac}}$ & $28.81 \pm 0.19^{\mathrm{bc}}$ & $2.49 \pm 0.02^{\mathrm{c}}$ \\
\hline & Kulumsa & 4 months & $75.81 \pm 1.31^{\mathrm{b}}$ & $29.69 \pm 0.39^{b}$ & $2.6 \pm 0.07^{\mathrm{ab}}$ \\
\hline
\end{tabular}




\begin{tabular}{|c|c|c|c|c|c|}
\hline Storage material & Location & Duration & Hardness index (\%) & Kernel weight (mg) & Kernel diameter $(\mathrm{mm})$ \\
\hline \multirow{3}{*}{ Jute bag } & Werer & 4 months & $78.01 \pm 1.19^{\mathrm{ab}}$ & $29.20 \pm 1.59^{\mathrm{a}}$ & $2.49 \pm 0.06^{\mathrm{a}}$ \\
\hline & Debrezeit & 4 months & $82.10 \pm 0.51^{\mathrm{c}}$ & $29.87 \pm 2.29^{\mathrm{a}}$ & $2.51 \pm 0.11^{\mathrm{a}}$ \\
\hline & Kulumsa & 4 months & $79.86 \pm 1.10^{\mathrm{ab}}$ & $31.82 \pm 0.87^{\mathrm{a}}$ & $2.62 \pm 0.03^{\mathrm{a}}$ \\
\hline \multirow{3}{*}{ PICS } & Werer & 6 months & $74.11 \pm 2.10^{\mathrm{bcd}}$ & $30.24 \pm 0.35^{\mathrm{a}}$ & $2.62 \pm 0.01^{\mathrm{a}}$ \\
\hline & Debrezeit & 6 months & $75.06 \pm 0.67^{\mathrm{c}}$ & $29.85 \pm 0.96^{\mathrm{a}}$ & $2.57 \pm 0.05^{\mathrm{a}}$ \\
\hline & Kulumsa & 6 months & $75.82 \pm 1.62^{\mathrm{b}}$ & $31.03 \pm 1.74^{\mathrm{a}}$ & $2.6 \pm 0.76^{\mathrm{a}}$ \\
\hline \multirow{2}{*}{ Polypropylene } & Werer & 6 months & $72.02 \pm 0.61^{\mathrm{d}}$ & $30.74 \pm 1.45^{\mathrm{abc}}$ & $2.59 \pm 0.08^{\mathrm{a}}$ \\
\hline & Kulumsa & 6 months & $76.22 \pm 1.41^{\mathrm{b}}$ & $29.31 \pm 1.05^{\mathrm{b}}$ & $2.53 \pm 0.05^{\mathrm{a}}$ \\
\hline \multirow{3}{*}{ Jute bag } & Werer & 6 months & $70.48 \pm 0.75^{\mathrm{d}}$ & $32.41 \pm 0.61^{\text {acd }}$ & $2.67 \pm 0.03^{\mathrm{cd}}$ \\
\hline & Debrezeit & 6 months & $76.99 \pm 1.15^{\mathrm{bc}}$ & $31.06 \pm 1.03^{\mathrm{abc}}$ & $2.61 \pm 0.06^{\mathrm{bc}}$ \\
\hline & Kulumsa & 6 months & $78.32 \pm 1.49^{b}$ & $30.19 \pm 0.43^{b}$ & $2.59 \pm 0.03^{b}$ \\
\hline
\end{tabular}

Table 1 above shows that wheat stored in PICS, Propylene and Jute bag for 6 months at Werer, Debrezeit, and Kulumsa had significant decrement in hardness index and Werer Jute bag had the lowest hardness index (70.48\%) compared to the control hardness index (79.78\%) but no significant difference in weight and diameter except diameter significant increment on wheat stored in Jute bag at Werer, Debrezeit and Kulumsa ( $2.67 \mathrm{~mm}, 2.61 \mathrm{~mm}$, and $2.59 \mathrm{~mm}$ respectively) compared to the control diameter of $2.58 \mathrm{~mm}$. Flour yield is related to kernel hardness, in hard varieties, there is an easier separation between bran and endosperm to obtain more fine flour as compared to soft varieties; flour yield of a test weight above $77.4 \mathrm{~kg} / \mathrm{hl}$ liter tends to be at the optimum milling yield i.e. above 70 percent; flour yield is positively correlated to test weight i.e. above $77.4 \mathrm{~kg} / \mathrm{hl}$, optimum milling yield was observed; wheat with lower test weight generally yields poor extraction rate [11].

Data are based on three replications; 2 Means followed by the same letter are not significantly different at Tukey's 5\% level of significance

As table 1 above shows wheat stored in PICS, Propylene, and Jute bag for 6 months has significantly reduced hectoliter weight compared to the control. Wheat stored at Debrezeit in Jute bag and PICS had the lowest hectoliter weight (70.5 $\mathrm{Kg} / \mathrm{hl}$ and $70.22 \mathrm{Kg} / \mathrm{hl}$ ) respectively) compared to the control hectoliter weight $(78.2 \mathrm{Kg} / \mathrm{hl})$. According to [12]. storage period had a significant impact on hectoliter weight decrement after 4 months of storage and this study is in agreement with [12] that the control $(78.2 \mathrm{~kg} / \mathrm{hl})$ was significantly higher than wheat stored in different storage materials at different locations; the wheat stored at Werer in Jute bag had higher hectoliter weight $(73 \mathrm{~kg} / \mathrm{hl})$ compared to other storage materials in different locations and Debrezeit PICS is the lowest hectoliter weight $(70.22 \mathrm{~kg} / \mathrm{hl})$. The storage period significantly affects test weight which decreases to the lowest value after 4 months [12]. The lowest value found from [12]. study was in jute bags with higher moisture content.

Table 2. Hectoliter weight and four yields of wheat stored in PICS, propylene and jute bag for 6 months concerning the storage location.

\begin{tabular}{lllll}
\hline Location & Storage material & Duration & Hectoliter weight & Germination potential \\
\hline Werer & PICS & 6 months & $83.00 \pm 1.41^{\mathrm{c}}$ & $83.00 \pm 1.41^{\mathrm{d}}$ \\
& Polypropylene & 6 months & $74.50 \pm 0.71^{\mathrm{e}}$ & $74.50 \pm 0.71^{\mathrm{c}}$ \\
& Jute bag & 6 months & $44.50 \pm 0.71^{\mathrm{g}}$ & $44.50 \pm 0.71^{\mathrm{b}}$ \\
Debrezeit & PICS & 6 months & $88.00 \pm 1.41^{\mathrm{a}}$ & $88.00 \pm 1.41^{\mathrm{a}}$ \\
& Polypropylene & 6 months & $81.50 \pm 2.12^{\mathrm{d}}$ & $81.50 \pm 2.12^{\mathrm{c}}$ \\
& Jute bag & 6 months & $45.00 \pm 1.41 \mathrm{f}$ & $85.00 \pm 1.41^{\mathrm{b}}$ \\
Kulumsa & PICS & 6 months & $86.50 \pm 2.12^{\mathrm{b}}$ & $86.50 \pm 2.12^{\text {abc }}$ \\
& Polypropylene & 6 months & $86.00 \pm 2.83^{\mathrm{b}}$ & $86.00 \pm 2.83^{\mathrm{bc}}$ \\
& Jute bag & 6 months & $81.00 \pm 1.41^{\mathrm{d}}$ & $81.00 \pm 1.41^{\mathrm{b}}$ \\
\hline
\end{tabular}

Means followed by different letters are significant at a $5 \%$ level for germination potential.

Table 3. Grain protein content, moisture content, falling number, and Flour yield of wheat stored at highland, midland and lowland in PICS, propylene, and jute bag after 2, 4 and 6 months of storage.

\begin{tabular}{|c|c|c|c|c|c|}
\hline Storage material & Location & Duration & Protein (\%) & Moisture (\%) & Falling number \\
\hline \multirow{3}{*}{ PICS } & Werer & 2 months & $13.29 \pm 0.01^{\mathrm{d}}$ & $12.55 \pm 0.04^{\mathrm{d}}$ & $813 \pm 5.66^{\mathrm{c}}$ \\
\hline & Debrezeit & 2 months & $13.13 \pm 0.01^{\mathrm{c}}$ & $11.98 \pm 0.02^{\mathrm{c}}$ & $829 \pm 9.89^{c}$ \\
\hline & Kulumsa & 2 months & $13.12 \pm 0.03^{\mathrm{b}}$ & $11.77 \pm 0.09^{b}$ & $876 \pm 7.07^{b}$ \\
\hline \multirow{3}{*}{ Polypropylene } & Werer & 2 months & $12.93 \pm 0.03^{\mathrm{a}}$ & $12.49 \pm 0.01^{\mathrm{c}}$ & $908 \pm 31.11^{\mathrm{d}}$ \\
\hline & Debrezeit & 2 months & $12.88 \pm 0.03^{\mathrm{a}}$ & $11.94 \pm 0.01^{b}$ & $734 \pm 13.44^{c}$ \\
\hline & Kulumsa & 2 months & $12.92 \pm 0.01^{\mathrm{a}}$ & $11.95 \pm 0.04^{b}$ & $805 \pm 23.33^{b}$ \\
\hline \multirow{2}{*}{ Jute bag } & Werer & 2 months & $12.46 \pm 0.64^{\mathrm{ac}}$ & $12.39 \pm 0.04^{\mathrm{d}}$ & $999 \pm 4.95^{\mathrm{d}}$ \\
\hline & Kulumsa & 2 months & $13.54 \pm 0.08^{\mathrm{ab}}$ & $13.10 \pm 0.00^{\mathrm{b}}$ & $957 \pm 0.71^{b}$ \\
\hline \multirow{3}{*}{ PICS } & Werer & 4 months & $12.84 \pm 0.01^{\mathrm{d}}$ & $11.63 \pm 0.02^{d}$ & $879 \pm 44.55^{\mathrm{c}}$ \\
\hline & Debrezeit & 4 months & $13.02 \pm 0.01^{\mathrm{c}}$ & $11.85 \pm 0.00^{\mathrm{c}}$ & $798 \pm 14.85^{\mathrm{b}}$ \\
\hline & Kulumsa & 4 months & $13.36 \pm 0.01^{\mathrm{b}}$ & $11.73 \pm 0.01^{\mathrm{b}}$ & $796 \pm 0.71^{\mathrm{b}}$ \\
\hline
\end{tabular}




\begin{tabular}{llllll}
\hline Storage material & Location & Duration & Protein (\%) & Moisture (\%) & Falling number \\
\hline \multirow{3}{*}{ Polypropylene } & Werer & 4 months & $13.34 \pm 0.00^{\mathrm{b}}$ & $11.64 \pm 0.04^{\mathrm{c}}$ & $928 \pm 31.81^{\mathrm{d}}$ \\
& Debrezeit & 4 months & $12.86 \pm 0.04^{\mathrm{a}}$ & $11.79 \pm 0.01^{\mathrm{b}}$ & $753 \pm 28.28^{\mathrm{c}}$ \\
& Kulumsa & 4 months & $12.85 \pm 0.01^{\mathrm{a}}$ & $11.77 \pm 0.03^{\mathrm{b}}$ & $864 \pm 9.89^{\mathrm{b}}$ \\
& Werer & 4 months & $13.22 \pm 0.01^{\mathrm{b}}$ & $11.29 \pm 0.02^{\mathrm{d}}$ & $1044 \pm 72.12^{\mathrm{c}}$ \\
Jute bag & Debrezeit & 4 months & $13.27 \pm 0.11^{\mathrm{b}}$ & $11.83+0.01^{\mathrm{c}}$ & $777 \pm 12.02^{\mathrm{b}}$ \\
& Kulumsa & 4 months & $13.26 \pm 0.11^{\mathrm{b}}$ & $11.97 \pm 0.03^{\mathrm{b}}$ & $827 \pm 12.02^{\mathrm{b}}$ \\
& Werer & 6 months & $12.93 \pm 0.01^{\mathrm{a}}$ & $11.05 \pm 0.04^{\mathrm{d}}$ & $914 \pm 35.36^{\mathrm{c}}$ \\
PICS & Debrezeit & 6 months & $12.74 \pm 0.03^{\mathrm{c}}$ & $11.89 \pm 0.01^{\mathrm{c}}$ & $831 \pm 21.92^{\mathrm{b}}$ \\
& Kulumsa & 6 months & $13.29 \pm 0.01^{\mathrm{b}}$ & $11.67 \pm 0.04^{\mathrm{b}}$ & $694 \pm 25.46^{\mathrm{a}}$ \\
Polypropylens & Werer & 6 months & $13.32 \pm 0.01^{\mathrm{c}}$ & $10.92 \pm 0.06^{\mathrm{c}}$ & $899 \pm 10.61^{\mathrm{d}}$ \\
& Debrezeit & 6 months & $12.83 \pm 0.02^{\mathrm{ab}}$ & $11.67 \pm 0.01^{\mathrm{b}}$ & $780 \pm 1.41^{\mathrm{c}}$ \\
& Kulumsa & 6 months & $12.75 \pm 0.08^{\mathrm{b}}$ & $11.70 \pm 0.01^{\mathrm{b}}$ & $727 \pm 27.58^{\mathrm{b}}$ \\
Jute bag & Werer & 6 months & $13.08 \pm 0.04^{\mathrm{c}}$ & $10.52 \pm 0.01^{\mathrm{d}}$ & $959 \pm 9.89^{\mathrm{c}}$ \\
& Debrezeit & 6 months & $13.13 \pm 0.04^{\mathrm{c}}$ & $11.55 \pm 0.02^{\mathrm{c}}$ & $844 \pm 28.99^{\mathrm{b}}$ \\
\hline
\end{tabular}

As table 3 above shows that wheat stored in PICS, Polypropylene and Jute bag for 4, 6 months at Werer, Debrezeit, and Kulumsa had significant decrement in milling yield, Debrezeit jute bag had the lowest flour yield of $26.34 \%$ from the control $(44.12 \%)$; but no significant difference among wheat stored in PICS at Werer, Debrezeit, and Kulumsa; no significant difference among wheat stored in Polypropylene at Werer, Debrezeit and Kulumsa and also no significant difference among wheat stored in Jute bag at Werer, Debrezeit, and Kulumsa. Flour yield is related to kernel hardness in hard varieties there is an easier separation between bran and endosperm to obtain more fine flour as compared to soft varieties [12].

Falling number is inversely proportional to $\alpha$-amylase activity; there is a direct relationship between enzyme activity and finished product attributes; falling number value of greater than 250 is generally acceptable for bread making. As the amount of enzyme activity increases, the falling number decreases. Values below 200 seconds indicate high levels of enzyme activity; [9] described that Pakistani wheat varieties are low in amylase activity as indicated by their falling numbers exceeding 400 seconds [9]. and the Lemu wheat variety in Ethiopia also had shown falling number value greater than 400 seconds too. The variation in the gluten content of various wheat varieties could occur due to environmental factors and genetic potentiality to accumulate proteins in the seed [12]. The table above showed a higher falling number value of wheat stored in jute bag at Werer, Debrezeit, and Kulumsa which is in agreement with the study of Raza et. al. (2010) that the highest falling number was found on wheat stored in jute bags [12].

Table 4. Gluten quality and quantity of wheat stored at highland, midland, and lowland in PICS, propylene, and jute bag after 2, 4 and 6 months of storage.

\begin{tabular}{|c|c|c|c|c|c|}
\hline Storage material & Location & Duration & Wet gluten & Dry gluten & Gluten index \\
\hline \multirow{3}{*}{ PICS } & Werer & 2 months & $33.67 \pm 3.59^{\mathrm{a}}$ & $17.3 \pm 3.05^{\mathrm{ab}}$ & $83.27 \pm 5.83^{\mathrm{a}}$ \\
\hline & Debrezeit & 2 months & $29.9 \pm 0.44^{\mathrm{a}}$ & $15.1 \pm 0.62^{\mathrm{a}}$ & $87.17 \pm 5.61^{\mathrm{a}}$ \\
\hline & Kulumsa & 2 months & $33.3 \pm 2.26^{\mathrm{a}}$ & $17.23 \pm 0.12^{\mathrm{a}}$ & $85.38 \pm 6.43^{\mathrm{a}}$ \\
\hline \multirow{3}{*}{ Polypropylene } & Werer & 2 months & $31.93 \pm 3.03^{\mathrm{a}}$ & $16.6 \pm 2.18^{\mathrm{ad}}$ & $82.56 \pm 6.57^{\mathrm{a}}$ \\
\hline & Debrezeit & 2 months & $28.47 \pm 1.76^{\mathrm{a}}$ & $11.9 \pm 3.84^{\mathrm{ac}}$ & $88.65 \pm 4.5^{a}$ \\
\hline & Kulumsa & 2 months & $31.83 \pm 1.69^{\mathrm{a}}$ & $16.43 \pm 1.01^{\mathrm{ab}}$ & $82.15 \pm 5.81^{\mathrm{a}}$ \\
\hline \multirow{2}{*}{ Jute bag } & Werer & 2 months & $32.97 \pm 0.25^{\mathrm{a}}$ & $16.67 \pm 1.11^{\mathrm{a}}$ & $82.48 \pm 3.26^{\mathrm{ac}}$ \\
\hline & Kulumsa & 2 months & $29.33 \pm 4.86 a$ & $16.87 \pm 0.06^{\mathrm{a}}$ & $85.1 \pm 2.55^{\mathrm{a}}$ \\
\hline \multirow{3}{*}{ PICS } & Werer & 4 months & $35.27 \pm 1.63 \mathrm{~d}$ & $19.07 \pm 0.78^{\mathrm{d}}$ & $77.33 \pm 3.37^{\mathrm{a}}$ \\
\hline & Debrezeit & 4 months & $39.3 \pm 1.37 c$ & $19.7 \pm 0.72^{\mathrm{c}}$ & $62.53 \pm 6.04^{c}$ \\
\hline & Kulumsa & 4 months & $37.3 \pm 1.76 b$ & $19.27 \pm 1.38^{\mathrm{b}}$ & $73.88 \pm 7.87^{\mathrm{b}}$ \\
\hline \multirow{3}{*}{ Polypropylene } & Werer & 4 months & $35.7 \pm 0.25 a$ & $20.3 \pm 0.95^{\mathrm{c}}$ & $74.81 \pm 1.50^{b}$ \\
\hline & Debrezeit & 4 months & $37.13 \pm 3.23 a$ & $18.83 \pm 1.07^{b c}$ & $67.58 \pm 2.33^{c}$ \\
\hline & Kulumsa & 4 months & $36 \pm 3.08 \mathrm{a}$ & $17.9 \pm 1.36^{\mathrm{ab}}$ & $77.44 \pm 3.91^{\mathrm{b}}$ \\
\hline Jute bag & Kulumsa & 4 months & $37.13 \pm 3.74 b$ & $19.3 \pm 2.74^{\mathrm{b}}$ & $66.13 \pm 8.07^{\mathrm{b}}$ \\
\hline \multirow{3}{*}{ PICS } & Werer & 6 months & $32.27 \pm 1.67 \mathrm{ac}$ & $16.23 \pm 3.05^{\mathrm{d}}$ & $89.26 \pm 1.43^{\mathrm{a}}$ \\
\hline & Debrezeit & 6 months & $36.5 \pm 0.95 b c$ & $18.17 \pm 0.62 c$ & $69.18 \pm 5.43^{\mathrm{bc}}$ \\
\hline & Kulumsa & 6 months & $37.7 \pm 2.49^{\mathrm{b}}$ & $19.27 \pm 0.12^{b}$ & $73.88 \pm 6.32^{\mathrm{b}}$ \\
\hline \multirow{3}{*}{ Polypropylene } & Werer & 6 months & $32.6 \pm 0.72^{\mathrm{a}}$ & $15.57 \pm 1.83^{\mathrm{d}}$ & $85.99 \pm 1.49^{\mathrm{ac}}$ \\
\hline & Debrezeit & 6 months & $34.27 \pm 1.27^{\mathrm{a}}$ & $17.53 \pm 1.21^{\mathrm{c}}$ & $78.33 \pm 4.80^{\mathrm{abc}}$ \\
\hline & Kulumsa & 6 months & $36.0 \pm 3.95^{\mathrm{b}}$ & $17.9 \pm 3.38^{\mathrm{b}}$ & $78.11 \pm 6.09^{\mathrm{ab}}$ \\
\hline \multirow{3}{*}{ Jute bag } & Werer & 6 months & $35.73 \pm 1.81^{\mathrm{bc}}$ & $17.93 \pm 1.53^{\mathrm{ac}}$ & $71.19 \pm 10.39^{\mathrm{abc}}$ \\
\hline & Debrezeit & 6 months & $32.4 \pm 0.92^{\mathrm{abc}}$ & $16.1 \pm 0.20^{\mathrm{abc}}$ & $81.63 \pm 2.32^{\mathrm{ab}}$ \\
\hline & Kulumsa & 6 months & $37.27 \pm 5.44^{\mathrm{b}}$ & $15.9 \pm 2.98^{\mathrm{ab}}$ & $68.37 \pm 10.15^{b}$ \\
\hline
\end{tabular}


Table 4 above shows that among the different storage materials, the jute bag at Werer and Kulumsa had shown lower gluten content $(64.89 \%, 68.37 \%)$ than the control gluten index $(85.18 \%)$, gluten index at polypropylene $(85.99 \%)$ and PICS $(89.26 \%)$ at Werer and gluten index polypropylene $(77.44 \%)$ and PICS (73.88\%) at Kulumsa and also wheat stored in PICS at Debrezeit showed a significant reduction in gluten index $(69.18 \%)$ compared to the control gluten index $(85.18 \%)$ after 6 months of storage. Wheat stored at Werer and Debrezeit in PICS, Propylene, and Jute bag had a significant increment in falling number value compared to the control. Meanwhile, there was no significant difference in the falling number value of wheat stored at Kulumsa in PICS, Propylene and Jute bag after 6 months' storage.

\section{Conclusion}

Wheat stored in a Jute bag at Werer for 6 months had a lower final germination percentage, lower gluten index, and higher falling number value. In addition, wheat stored at Werer in jute bag had reduced hardness index value but the increment in grain diameter. Meanwhile, wheat stored in a Jute bag at Debrezeit for 6 months had a lower final germination Percentage, lower hectoliter weight but an insignificant change in the hardness index value. Wheat stored at low land, midland and highland in a jute bag for 4 and 6 months had shown increment in protein content. Wheat stored at Debrezeit in jute bag and PICS for 6 months had lower hectoliter weight and flour yield percentage. Besides, wheat stored at Debrezeit in a jute bag for 4 months of storage had higher wet and dry gluten content but lower gluten index value. Wheat stored at low land, midland and highland in a jute bag for 4 and 6 months had shown increment in protein content while KARC indicated good in all aspects Wheat stored at Debrezeit in a jute bag and PICS for 6 months had lower hectoliter weight and flour yield percentage. Besides, wheat stored at Debrezeit in a jute bag for 4 months of storage had higher wet and dry gluten content but lower gluten index value.

Generally, PICS and polypropylene packaging materials are more effective than jute bags and the highland environment had less effect on stored wheat quality.

\section{Recommendation}

Jute bag would not be used for grain stored while PICS bag and polypropylene should be used at a highland environment with less reduction of wheat physicochemical properties. Further research is conducted in the future on stored wheat product quality and microbial quality including stored wheat flour Some nutritional compositions also be conducted for clear recommendations for stored wheat quality like fat, carbohydrate. On different wheat varieties to select defect resistance during wheat storage.

\section{References}

[1] Kalsa, K. K., Subramanyam, B., Demissie, G., Mahroof, R., Gabbiye, N., Fanta, Admasu, Solomon, Workneh, (2018). Major insects and their associated losses in stored wheat in Ethiopia. In: 1st National Conference on Post-Harvest Management for Improved Livelihood and Sustainable Development (Book of Abstracts), 10 May 2018. Bahir Dar Institute of Technology, Bahir Dar, Ethiopia.

[2] Kalsa, K. K., Subramanyam, B., Demissie, G., Mahroof, R., Gabbiye, N., 2017. Efficacy of filter cake against Sitophilus granarius L. And Rhyzopertha Dominica F. In stored wheat. In: 1st All Africa Post-Harvest Congress and Exhibition, pp. $118 \mathrm{e} 120$ (Nairobi).

[3] Karta K., Bhadriraju S., Girma D., Rizana M., Admasu W., and Nigus G. (2019). Evaluation of postharvest preservation strategies for stored wheat seed in Ethiopia, Journal of Stored Products Research journal homepage: www.elsevier.com/locate/jspr.

[4] Martin, D. T. T., Baributsa, D., Huesing, J. E. E., Williams, S. B. B., and Murdock, L. L. L., (2015). PICS bags protect wheat grain, Triticum aestivum (L.), against rice weevil, Sitophilus oryzae (L.) (Coleoptera: Curculionidae). J. Stored Prod. Res. 63, 22e30. https://doi.org/10.1016/j.jspr.2015.05.001.

[5] Baoua, I. B., Amadou, L., Lowenberg-DeBoer, J. D., Murdock, L. L., 2013. Side by side comparison of GrainPro and PICS bags for postharvest preservation of cowpea grain in Niger. J. $\begin{array}{llll}\text { Stored } & \text { Prod. } & \text { Res. }\end{array}$ https://doi.org/10.1016/j.jspr.2013. 03.003.

[6] Bishaw, Z., Atilaw, A., (2016). Enhancing agricultural sector development in Ethiopia: the role of research and seed sector. Ethiop. J. Agric. Sci. Special Is 101e130.

[7] Dessalegn, T., Tesfaye, S., Gebrekristos, T., Abiy, S., Shure, S., Yazzie, C., Subramanyam, B., Roberts, K. A., Abay, F., Mahroof, R., (2017). Post-harvest wheat losses in Africa: an Ethiopian case study. In: Langridge, P. (Ed.), Achieving Sustainable Cultivation of Wheat Volume 2: Cultivation Techniques. Burleigh Dodds Science Publishing, pp. 85e104. https://doi.org/10.19103/ AS.2016.0004.18.

[8] AACC. 2000. Approved Methods of American Association of Cereal Chemists. Amer. Assoc. of Cereal Chemists. Inc., St. Paul, Minnesota, USA.

[9] Buriro M., Oad F. C., Keerio, M. I., Gandahi A. W., and Laghari G. M. (2012). Impact of storage sources on physicochemical properties of various wheat varieties. Sarhad $J$. Agric, 28 (2), pp. 185-190.

[10] Chattha S. H., Jamali L. A., Ibupoto K. A., and Mangio H. R. (2012). Effect of different packaging materials and storage conditions on the viability of wheat seed (TD-1 variety). Sci., Tech. and Dev., 31 (1). 10-18.

[11] Jafri S. (2010). Physicochemical changes affecting the nutritional and technological of wheat grains stored in different types of containers. $\mathrm{PhD}$ dissertation thesis. Arid Agricultural University. Rawalpindi. Pakistan. 
[12] Raza S,, Khalil S., Naseem K., Gilani M. A., Amjad M., Masud T. and Naqvi S. M. S. (2010). Effect of household storage receptacles on physicochemical characteristics of wheat. Sarhad J. Agri, 26 (2).

[13] Rehman, Z. U. and Shah. W. H. (1999). Biochemical changes in wheat during storage at three temperatures. Plant Food Hum. Nut. 54. 109-117.
[14] Strelec I, Popović R., Ivanišić I., Jurković V., Jurković Z., Ugarčić-Hardi Z., Sabo M. (2010). Influence of temperature and relative humidity on grain moisture, germination and vigour of three wheat cultivars during one year storage. POLJOPRIVREDA. 16 (2). 20-24. 